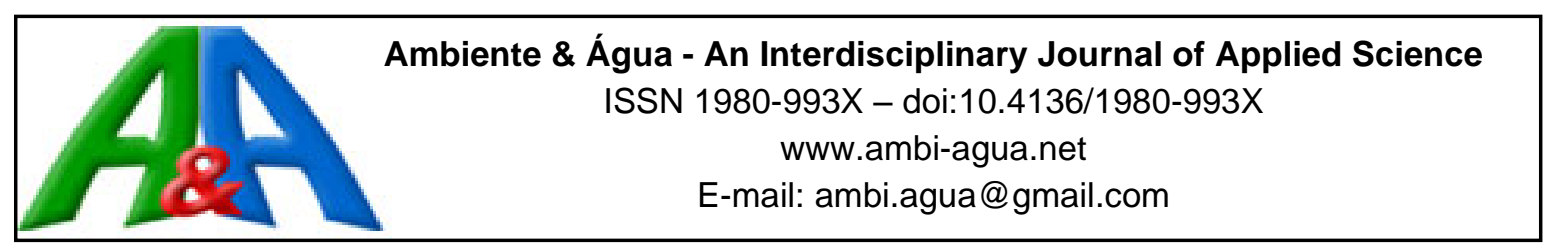

\title{
Tolerance of lead by forage peanut cultivated in two soil classes
}

\author{
doi:10.4136/ambi-agua.2332 \\ Received: 20 Nov. 2019; Accepted: 27 Dec. 2019 \\ Josy Karla de Oliveira Santos'; Ana Aparecida da Silva Almeida ${ }^{2 *}$; \\ Julio Cesar Raposo de Almeida ${ }^{2}$; Paula Blamberg Ribeiro da Silva ${ }^{1}$
${ }^{1}$ Programa de Pós-graduação em Ciências Ambientais. Universidade de Taubaté (UNITAU), Rua Visconde do Rio Branco, n² 210, CEP: 12020-240, Taubaté, SP, Brazil. E-mail: josy-karla@ hotmail.com, paula.blam89@gmail.com
${ }^{2}$ Instituto Básico de Biociências. Universidade de Taubaté (UNITAU), Av. Tiradentes, 500, CEP 12030-180, Taubaté, SP, Brazil. E-mail: jcraposo@uol.com.br *Corresponding author. E-mail: anaparecida.almeida@gmail.com

\begin{abstract}
This work evaluated the potential of lead $(\mathrm{Pb})$ phytoextraction by forage peanut, Arachis pintoi, cultivated on an Oxisol and a Gleysol. The samples of these soils received $\mathrm{Pb}$ as lead acetate heptahydrate $\left(\mathrm{Pb}\left(\mathrm{C}_{2} \mathrm{H}_{3} \mathrm{O}_{2}\right)_{2} .7 \mathrm{H}_{2} \mathrm{O}\right)$ at rates of 0,150 and $300 \mathrm{mg} \mathrm{kg}^{-1}$. The plants were cultivated in pots filled with $\mathrm{Pb}$ contaminated soil, and 105 days after planting were collected to determine shoot and root dry matter. Lead contents in soil and plant samples were determined using an atomic absorption spectrophotometer. Lead did not affect shoot dry matter yield in both soil classes, but linearly reduced root dry matter. The highest $\mathrm{Pb}$ concentration in the plant was detected in the A. pintoi shoot. This species is not a $\mathrm{Pb}$ accumulator but may be considered $\mathrm{Pb}$ tolerant and is indicated for revegetation programs in $\mathrm{Pb}$-polluted soils.
\end{abstract}

Keywords: Arachis pintoi, gleysol, oxisol, polluted soil.

\section{Tolerância ao chumbo por amendoim forrageiro cultivado em duas classes de solo}

\section{RESUMO}

Este trabalho avaliou o potencial de fitoextração de chumbo $(\mathrm{Pb})$ pelo amendoim forrageiro, Arachis pintoi, cultivado em Latossolo e Gleissolo. Amostras destes solos receberam $\mathrm{Pb}$ na forma de acetato de chumbo hepta-hidratado $\left.\left(\mathrm{Pb}\left(\mathrm{C}_{2} \mathrm{H}_{3} \mathrm{O}_{2}\right)_{2}\right) \cdot 7 \mathrm{H}_{2} \mathrm{O}\right)$ nas doses 0,150 e $300 \mathrm{mg} \mathrm{kg}^{-1}$. As plantas foram cultivadas em caixas de acrílico preenchidas com as amostras de solo com as doses de $\mathrm{Pb}$, e após 105 dias do plantio foram coletadas para determinação da matéria seca da parte aérea e da raiz. Os teores de $\mathrm{Pb}$ no solo e nas partes da planta foram determinados usando um espectrofotômetro de absorção atômica. O chumbo não afetou a produção de matéria seca da parte aérea nas duas classes de solo, mas reduziu linearmente a matéria seca das raízes. A maior concentração do $\mathrm{Pb}$ na planta foi detectada na parte aérea de Arachis pintoi. Essa espécie pode ser considerada tolerante, mas não um acumulador de $\mathrm{Pb}$ sendo indicado para programas de revegetação em solos poluídos por $\mathrm{Pb}$.

Palavras-chave: Arachis pintoi, gleissolo, latossolo, poluição do solo. 


\section{INTRODUCTION}

The Paraíba do Sul river basin is part of the territories of the states of São Paulo, Rio de Janeiro and Minas Gerais, constituting one of the most important industrial regions of Brazil. In this region, physical, chemical and biological soil problems resulting from anthropogenic activities such as improper waste disposal, road construction, dams, mining activities and improperly managed agricultural areas are frequent, resulting in soil contamination by metals.

In this watershed Soares et al. (2008) documented the occurrence of Oxisols and Gleysols, which present very distinct pedological characteristics, such as the greater presence of clay and organic matter in the Gleysols. Silva et al. (2013) studying lead $(\mathrm{Pb})$ and zinc $(\mathrm{Zn})$ occurrence on the edges of a high-traffic highway in the Paraiba do Sul basin, found that these metals were higher in soil samples closer to the highway edge, decreasing with increasing distance from the road.

To minimize the negative environmental impacts of soil contamination by heavy metals, phytoremediation is a viable practice and has lower operating costs compared to other forms of soil decontamination such as physical removal of the contaminated layer (Oliveira et al., 2006; Sana et al., 2016).

Phytoremediation can be classified into various techniques such as rhizodegradation, phytovolatilization, phytoextraction, phytotransformation, phytodegradation, phytostabilization, and phytofiltration (Ullah et al., 2015).

Phytoextraction uses accumulator plants for the uptake of vast quantities of heavy metals from soil and storage of these in a harvestable component, i.e., shoots (Andrade et al., 2009; Bhargava et al., 2012; Kamram et al., 2014). Other characteristics essential for the success of phytoextraction are the ability of the plant to grow out of its place of origin with rapid growth, high biomass production and easy harvesting.

Lead has been considered as a target pollutant of remediation studies due to its widespread distribution, persistence, and toxicity in relation to human health (Sharma and Dubey, 2005). $\mathrm{Pb}$ is ranked the number two pollutant in the called the priority list of hazardous substances that be offer health risks (ATSDAR, 2017).

In soils contaminated by $\mathrm{Pb}$ plants may present physiological disorders such as decreased biomass, chlorosis, inhibition of photosynthesis, and changes in water and hormonal balance (Paiva et al., 2002; Sharma and Dubey, 2005). However, some plant species have tolerance to this toxic effect, like Mimosa caesalpiniaefolia (Souza, 2010), Mucuna aterrima (Santos et al., 2012), Populus nigra (Redovniković et al., 2017) and Ricinus communis (Kiran and Prasad, 2017).

The plant Arachis pintoi is commonly referred to as forage peanut and is widespread in the tropical and subtropical areas of Brazil and the world (Nascimento, 2006). It is a Fabaceae (Papilionoideae) native to Argentina, Bolivia, Paraguay, Uruguay and especially Brazil, and grows well in low to medium fertility soil with high aluminum saturation.

This perennial herbaceous species reaches 20 to $50 \mathrm{~cm}$ height with stoloniferous growth. Usually, it releases dense quantities of branched stolons, which root up to $1.50 \mathrm{~m}$ horizontally in all directions and can reproduce sexually and vegetatively (Montenegro and Pinzón, 1997; Lima et al., 2003, Miranda et al, 2008).

It is frequently used as forage in grass-intercropping pastures (Lima et al., 2003), but due to their excellent ground cover, with a dense layer of stolons and ability to grow under shading, in addition to providing biological nitrogen fixation, it can also be used to control erosion and assist in recovery of degraded areas (Miranda et al., 2008).

The aim of this experiment was to evaluate the potential of lead $(\mathrm{Pb})$ phytoextraction by forage peanut, Arachis pintoi, from contaminated Oxisol and Gleysol soils. 


\section{MATERIALS AND METHODS}

\subsection{Soil characterization}

Soil samples from an Oxisol and Gleysol were collected at the 0-20 cm depth under native vegetation in Taubaté, SP, Brazil. The soil samples were air dried and homogenized but did not receive any corrective treatment in this experiment (Table 1).

Table 1. Soil chemical properties before application of treatments.

\begin{tabular}{ccccccccccccccc}
\hline & $\mathbf{p H}$ & $\mathbf{O M}$ & $\mathbf{P}$ & $\mathbf{K}$ & $\mathbf{C a}$ & $\mathbf{M g}$ & $\mathbf{H}+\mathbf{A l}$ & $\mathbf{S B}$ & $\mathbf{C E C}$ & $\mathbf{V}$ & $\mathbf{C u}$ & $\mathbf{F e}$ & $\mathbf{M n}$ & $\mathbf{Z n}$ \\
\hline SOIL & $(\mathbf{C a C l})$ & $\left(\mathbf{g} / \mathbf{d m}^{\mathbf{3}}\right)$ & & \multicolumn{1}{c}{$\left(\mathbf{m m o l}_{\mathbf{c}} / \mathbf{d m}^{\mathbf{3}}\right)$} & & & $\boldsymbol{\%}$ & & & & \\
\hline Oxisol & 4.3 & 21.0 & 3.0 & 1.6 & 6.0 & 2.0 & 36.0 & 9.6 & 45.6 & 21.0 & 0.6 & 60.0 & 4.0 & 0.8 \\
Gleysol & 5.5 & 55.5 & 3.0 & 1.8 & 6.0 & 2.0 & 36.0 & 9.6 & 45.6 & 21.0 & 0.6 & 60.0 & 4.0 & 0.8 \\
\hline
\end{tabular}

$\mathrm{pH}$ in $\mathbf{C a C l}_{2}$ at a ratio of $1: 2.5 \mathrm{v} / \mathrm{v} . \mathrm{Ca}^{2+} . \mathrm{Mg}^{2+}$ and $\mathrm{Al}^{3+}$ extracted with $\mathrm{KCl}$ solution $\left(1 \mathrm{~mol} \mathrm{~L}^{-1}\right) ; \mathrm{P}$ and $\mathrm{K}$ extracted with Mehlich $^{-1} ; \mathrm{H}+\mathrm{Al}=\mathrm{SMP}$ buffer solution - $\mathrm{pH}$ 7.5; CEC at $\mathrm{pH}$ 7.0. $\mathrm{SB}=$ sum of bases; $\mathrm{Cu}^{2+}, \mathrm{Mn}^{2+}$ and $\mathrm{Al}^{3+}$ extracted with DTPA solution $\left(1 \mathrm{~mol} \mathrm{~L}^{-1}\right)$.

The soils were artificially contaminated with $\mathrm{Pb}$ as lead acetate heptahydrate $\left(\mathrm{Pb}\left(\mathrm{C}_{2} \mathrm{H}_{3} \mathrm{O}_{2}\right)_{2}\right) .7 \mathrm{H}_{2} \mathrm{O}$ at rates of 0 (Control), 150 and $300 \mathrm{mg} \mathrm{kg}^{-1}$. After adding $\mathrm{Pb}$, the soils were incubated for 35 days. Soil samples were taken from pots immediately after the incubation period to determine the extractable Pb using the DTPA solution (Raij et al., 2001).

\subsection{Pot experiment}

After the incubation period, samples of $\mathrm{Pb}$ contaminated soil were transferred to $2 \mathrm{~L}$ pots. The pots were maintained in a seedling nursery in a completely randomized factorial design with 6 treatments, combining lead-contaminated soil (Gleysol and Oxisol) at the $\mathrm{Pb}$ concentrations 0 (Control), 150, $300 \mathrm{mg} \mathrm{kg}^{-1}$ each consisting of five replicates.

In each pot, we used two green stolons, with $15 \mathrm{~cm}$ height, for vegetative propagation of Arachis pintoi, obtained from the Department of Agrarian Sciences, University of Taubaté, São Paulo, Brazil. The pots were irrigated two days per week.

The plants were harvested after 105 days after stolon planting. They were separated in shoot and root, washed with deionized water, dried at $65^{\circ} \mathrm{C}$ for $72 \mathrm{~h}$. After shoot dry matter (SM) and root dry matter (RM) determinations, these plant materials were finely ground to pass through a $1 \mathrm{~mm}$ sieve. Lead was extracted from the SM and RM samples ( $0.5 \mathrm{~g}$ each) which were digested in a mixture of nitric acid and perchloric acid (3:1) on a hot plate. Concentrations of $\mathrm{Pb}$ in the digested solutions was determined using atomic absorption spectrophotometry (Malavolta et al., 1997). The accumulated $\mathrm{Pb}$ was obtained as the $\mathrm{Pb}$ concentration multiplied by the dry matter.

All statistical analyses were performed using the SISVAR software (FERREIRA, 2014). The obtained results were submitted to analysis of variance, and in the case of a significant $F$ Test ( $\mathrm{p}<0.05)$ results were compared using a general linear model. For accumulated $\mathrm{Pb}$ the mean values were compared by Tukey's multiple comparison test.

\section{RESULTS AND DISCUSSION}

\subsection{Lead concentration in soils after incubation}

The effects of treatments on mean $\mathrm{Pb}$ concentrations in the soil were significant after the incubation period $(\mathrm{p}<0.05)$ for both soils (Figure 1), with an increase in extractable $\mathrm{Pb}$ in each treatment. The Brazilian standards defined by the Resolution CONAMA 420/2009 (Brazilian Environmental Council) consider soil contaminated when this value is above $72 \mathrm{mg} \mathrm{kg} \mathrm{kg}^{-1}$. Similarly, in the state of São Paulo, the Environmental Agency (CETESB) uses the same limit 
to indicate Pb contaminated soil CETESB (2016).

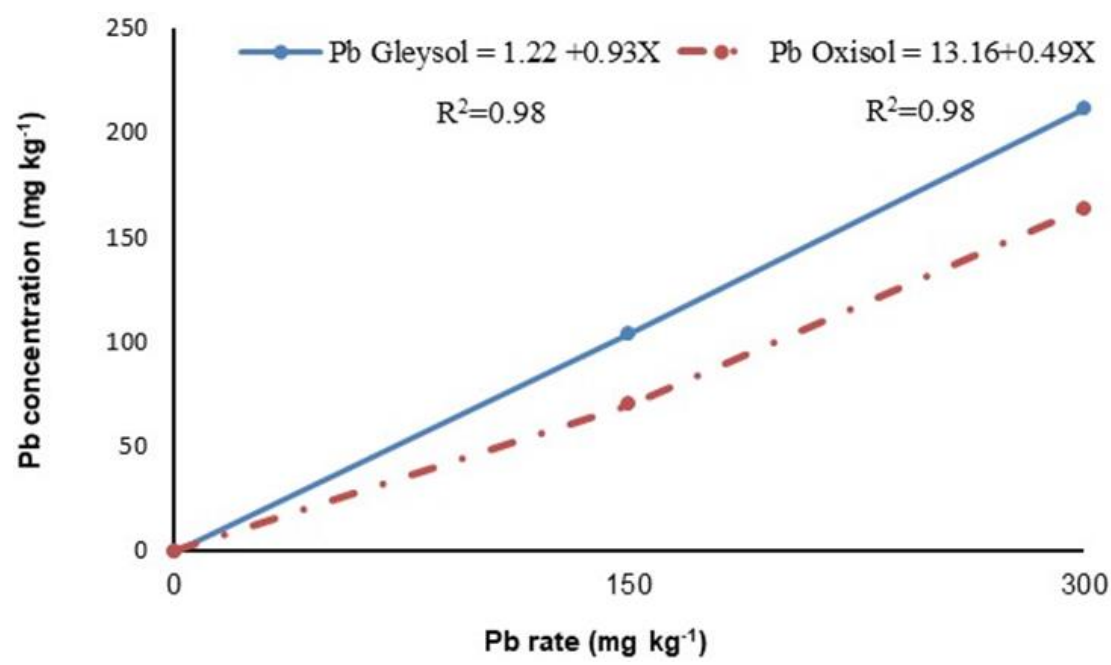

Figure 1. Lead concentration in soils after incubation for 35 days after contamination with lead treatments.

\subsection{Shoot dry matter (SM) and root dry matter (RM)}

The shoot dry matter was not affected by treatments $(p>0.05)$ reaching a mean of 4.05 g.pot ${ }^{-1}$. However, $\mathrm{Pb}$ rates linearly reduced the root dry matter (Figure 2). Reductions of dry matter production in many plant species as a function of doses of $\mathrm{Pb}$ in experiments with soil and nutrient solution were reported by other authors (Paiva et al., 2002; Sharma and Dubey, 2005; Lindino et al., 2012; Santos et al., 2012; Redovniković et al., 2017). In the current study the lead rates did not influence shoot dry matter production, which was similarly reported by Lindino et al. (2012) for Crotalaria spectabilis.

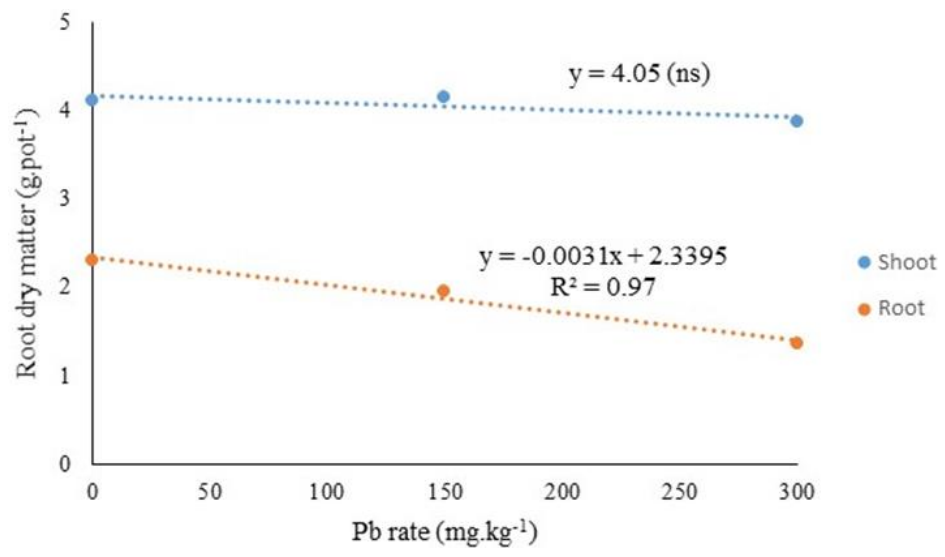

Figure 2. Root dry matter produced by forage peanut as affected by $\mathrm{Pb}$ treatments.

For shoot $\mathrm{Pb}$ concentration there were significant $(\mathrm{p}<0.01)$ effects of $\mathrm{Pb}$ rates and soil, with $\mathrm{Pb}$ concentration in forage peanut increasing linearly with $\mathrm{Pb}$ addition to soil (Figure 3 ).

The highest $\mathrm{Pb}$ concentration was observed in plant shoots cultivated in the Oxisol while the lowest concentration was observed in plants cultivated in the Gleysol. This result can be explained by the fact that phyto-availability of $\mathrm{Pb}$ decreases with an increase in clay content because of the generally high affinity of metals for the soil clay fraction (Kabata-Pendias and Pendias, 2001). 
The $\mathrm{Pb}$ concentration was lowest in forage peanut roots showing a significant increase in $\mathrm{Pb}$ translocation to the leaves (Figure 3). This finding is contrary to those reported by Santos et al. (2012) and Romeh et al. (2016) who reported higher amounts of lead in roots than in shoots.

No visual symptoms were observable in the shoots of the plant during the 105 days of the experiment, indicating that the forage peanut does not appear to be affected by excessive $\mathrm{Pb}$ concentration.

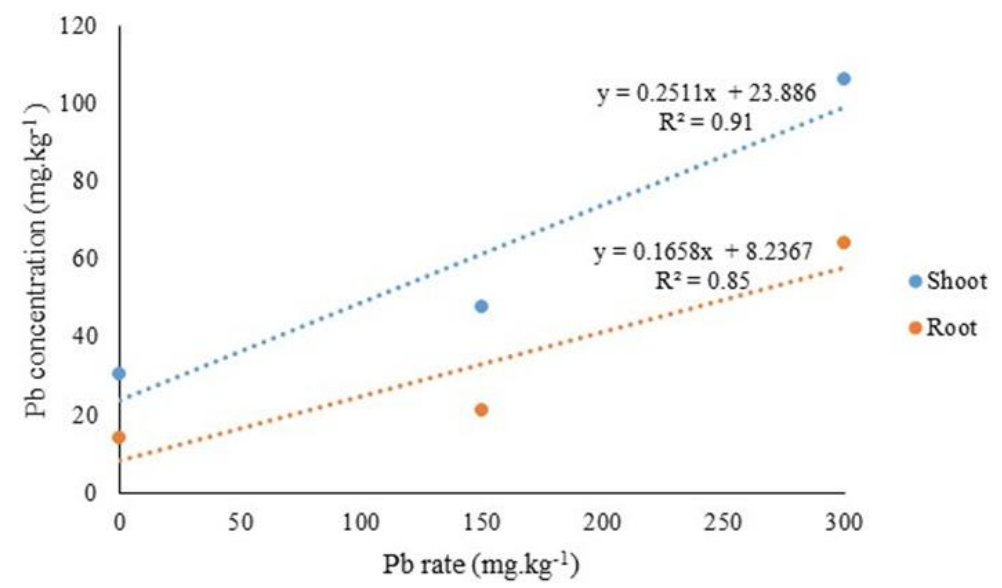

Figure 3. Lead concentration in forage peanut plants as affected by $\mathrm{Pb}$ treatments.

There was a significant effect ( $\mathrm{p}<0.05$ ) due to soil type and doses for $\mathrm{Pb}$ accumulation in the shoots and roots (Table 2). In the present study, $\mathrm{Pb}$ rates promoted higher $\mathrm{Pb}$ accumulation in roots than in shoots. There was a significant effect of the rates on the $\mathrm{Pb}$ accumulation in the shoots, with greater accumulation by cultivation on the Oxisol than the Gleysol.

Table 2. Lead accumulated in forage peanut as affected by $\mathrm{Pb}$ treatments.

\begin{tabular}{|c|c|c|c|c|c|c|c|}
\hline \multicolumn{8}{|c|}{$\mathrm{Pb}$ accumulated in shoots $\left(\mu \mathrm{g} \cdot\right.$ pot $\left.^{-1}\right)$} \\
\hline & 0 & & 150 & & 300 & & \\
\hline Gleysol & 13.88 & & 23.88 & & 309.42 & & 115.72 \\
\hline \multirow[t]{2}{*}{ Oxisol } & 252.38 & & 407.56 & & 530.96 & & $396.97 \quad \mathrm{~A}$ \\
\hline & 133.13 & $\mathrm{~b}$ & 216.72 & $\mathrm{~b}$ & 420.19 & $\mathrm{a}$ & \\
\hline \multicolumn{8}{|c|}{$\mathrm{Pb}$ accumulated in roots $\left(\mu \mathrm{g} \cdot\right.$ pot $\left.^{-1}\right)$} \\
\hline \multicolumn{3}{|c|}{0} & 150 & \multicolumn{3}{|c|}{300} & \\
\hline Gleysol & 3.7 & $\mathrm{Bb}$ & 5.34 & $\mathrm{Bb}$ & 71.18 & $\mathrm{Aa}$ & 26.74 \\
\hline \multirow[t]{2}{*}{ Oxisol } & 71.28 & Aa & 85.82 & Aa & 70.86 & $\mathrm{Aa}$ & 75.79 \\
\hline & 37.49 & & 46.58 & & 71.02 & & \\
\hline
\end{tabular}

*Means followed by the same capital letters in a column, or small letters in a line, do not differ significantly by the Tukey test $(\mathrm{p}<$ $0.05)$.

The $\mathrm{Pb}$ accumulated in the shoots was lower in the Gleysol $\left(115.72 \mu \mathrm{g}_{\mathrm{g}} \mathrm{pot}^{-1}\right)$ than in the Oxisol $\left(396.97 \mu \mathrm{g}\right.$. pot $\left.^{-1}\right)$. The treatments significantly affected $(\mathrm{p}<0.05)$ the accumulation of $\mathrm{Pb}$ in the roots due to the soil, the $\mathrm{Pb}$ rates and the interaction of soil and rates, being lower in the Gleysol $\left(26.74 \mu \mathrm{g}\right.$.pot $\left.{ }^{-1}\right)$ than the Oxisol $\left(75.79 \mu \mathrm{g}_{\text {.pot }}{ }^{-1}\right)$. Lead accumulated in shoots was 3.43 times greater, and $\mathrm{Pb}$ accumulated in roots was 2.83 -fold higher in the plants cultivated on 
the Oxisol than those on the Gleysol. Approximately $78-88 \%$ of all accumulated $\mathrm{Pb}$ in the plant is retained in the shoot.

\section{CONCLUSIONS}

The results suggest that forage peanut is not a $\mathrm{Pb}$ accumulator but may be considered tolerant and is indicated for revegetation programs in $\mathrm{Pb}$-polluted soils. Also, the lead accumulation in forage peanut was higher in plants cultivated on an Oxisol than on a Gleysol.

\section{REFERENCES}

AGENCY FOR TOXIC SUBSTANCES AND DISEASE CONTROL - ATSDAR. CERCLA. The priority list of hazardous substances, 2017. Disponível em: < https://www.atsdr.cdc.gov/SPL/index.html\#2017spl >. Acesso em: 8 nov 2019.

ALVES, J. do C. et al. Potential of sunflower, castor bean, common buckwheat and vetiver as lead phytoaccumulators. Revista Brasileira de Engenharia Agrícola e Ambiental, v. 20, n. 3, p. 243-249, 2016.

ANDRADE, M. G.et al. Metais pesados em solos de área de mineração e metalurgia de chumbo. I - fitoextração. Revista Brasileira de Ciência do Solo, Viçosa, v. 33, n. 6, p. 18791888, 2009.

BHARGAVA, A. et al. Approaches for enhanced phytoextraction of heavy metals. Journal of environmental management, v. 105, p. 103-120, 2012.

CETESB. Valores orientadores para solos e águas subterrâneas. 2016. Disponível em: < https://cetesb.sp.gov.br/aguas-subterraneas/wp-content/uploads/sites/13/2013/11/ tabela_vos_2016_site.pdf>. Acesso em: 8 dec. 2019

CONAMA - Conselho Nacional do Meio Ambiente. 2009. Resolução no 420, de 28 de dezembro de 2009. Diário Oficial da República Federativa do Brasil, Brasília, DF, $\mathrm{n}^{\circ}$ 249 , de 30/12/2009, p. 81-84

KABATA-PENDIAS, A., PENDIAS, H. Trace Elements in Soils and Plants, 3ed. CRC Press, Boca Raton, FL, USA, 2001.

KAMRAN, M. A. et al. The potential of the flora from different regions of Pakistan in phytoremediation: a review. Environmental Science and Pollution Research, v. 21, n. 2, p. 801-812, 2014.

KIRAN, B. R.; PRASAD, M. N. V. Ricinus communis L. (Castor bean), a potential multipurpose environmental crop for improved and integrated phytoremediation. The EuroBiotech Journal, v. 1, n. 2, p. 101-116, 2017.

LIMA, J.A; PINTO, J.C. et al. Amendoim forrageiro (Arachis pintoi Krapov. \& Greg). 2003. Bol_01. Disponível em: http://www.editora.ufla.br/index.php/boletins-tecnicos-e-deextensao/boletins-de-extensao. Acesso em: 4 dez. 2019.

LINDINO, C. A. et al. Soil phytoremediation using Crotalaria spectabilis for removal of cadmium and lead. Scientia Agraria Paranaensis, v. 11, n. 4, p. 25-32, 2012.

MALAVOLTA, E. A.; VITTI, G. C.; OLIVEIRA, S. A. Avaliação do estado nutricional das plantas: princípios e aplicações. 2. ed. Piracicaba: Editora Potafós, 1997. 304 p. 
MIRANDA, E. M.; SAGGIN JUNIOR, O. J.; SILVA, E. M. R. Amendoim forrageiro: inportância, usos e manejo. Seropédica: Embrapa Agrobiologia, 2008. 85 p.

MONTENEGRO, R.; PINZÓN, B. Maní forrajero (Arachis pintoi Krapovickas e Gregory): Una alternativa para el sostenimiento de la ganaderia en Panamá. Panamá: IDIAP, 1997. 20p.

NASCIMENTO, I.S. O cultivo do amendoim forrageiro. Rev. Bras. Agrociência, v. 12, n. 4, p. 387-393, 2006.

OLIVEIRA, D. B. et al. Fitorremediação: estado da arte. Rio de Janeiro: CETEM/ MCT, 2006. 32 p. (Tecnologia Ambiental).

PAIVA, H. N.; CARVALHO, J. G.; SIQUEIRA, J. O. Índice de translocação de nutrientes em mudas de cedro (Cedrela fissilis Vell.) e de ipê-roxo (Tabebuia impetiginosa (Mart.) standl.) submetidas a doses crescentes de cádmio, níquel e chumbo. Revista Árvore, v. 26, n.4, p:467-473, 2002

RAIJ, B. van; ANDRADE, J. C. de; CANTARELLA, H.; QUAGGIO, J. A. Análise química para avaliação da fertilidade de solos tropicais. Campinas: Instituto Agronômico, 2001. 285 p.

REDOVNIKOVIĆ, I. R. et al. Poplar response to cadmium and lead soil contamination. Ecotoxicology and environmental safety, v. 144, p. 482-489, 2017.

ROMEH, A. A.; KHAMIS, M. A.; METWALLY, S. M. Potential of Plantago major L. for phytoremediation of lead-contaminated soil and water. Water, Air, \& Soil Pollution, v. 227, n. 1, p. 9, 2016.

SANTOS, C. H. et al. Utilização da mucuna preta (Mucuna aterrima Piper \& Tracy) para a fitorremediação de solo contaminado por chumbo. Agroambiente On-line, v. 6, n. 3, p. 215-221, 2012.

SHARMA P.; DUBEY, R. S. Lead toxicity in plants. Brazilian Journal Plant Physiology, v. 17, n.1, p. 35-52, 2005.

SOARES, P. V. et al. Map of infiltration of the Paraíba do Sul basin using physical elements and precipitation. Revista Ambiente \& Água, v. 3, n. 1, p. 26-42, 2008.

SOUZA, S. C. R. Tolerância aos metais pesados chumbo e zinco e potencial fitorremediador de mudas de espécies arbóreas, 2010, 85f. Dissertação (Mestrado em Biologia Vegetal) - Universidade de Campinas, Campinas, 2010.

ULLAH, A. et al. Phytoremediation of heavy metals assisted by plant growth promoting (PGP) bacteria: a review. Environmental and Experimental Botany, v. 117, p. 28-40, 2015.

ZIA, M. H. et al. Chemically enhanced phytoextraction of $\mathrm{Pb}$ by wheat in texturally different soils. Chemosphere, v. 79, n. 6, p. 652-658, 2010. 